\title{
Faktor-faktor yang mempengaruhi kinerja keuangan pada bank umum syariah di Indonesia
}

\author{
Suratminingsih $^{1}$, Patriandari*2 ${ }^{2}$, Sari Mujiani ${ }^{3}$, Nur Rizkiyana ${ }^{4}$ \\ STEBIS Bina Mandiri, Bogor ${ }^{1}$, Universitas Islam As-Syafi' iyah, Jakarta ${ }^{2,3,4}$ \\ mimin.campus@gmail.com, * patriandari.feb@uia.ac.id,sarimujiani.feb@uia.ac.id, \\ n.rizkiyana15@gmail.com
}

\begin{abstract}
*Penulis Korespondensi
Diajukan : 1 Januari 2022

Disetujui : 15 Januari 2022

Dipublikasi : 17 Januari 2022
\end{abstract}

\begin{abstract}
This study aims to determine the effect of mudharabah, musyarakah, murabahah, and ijarah financing on banking performance. The population in this study includes Islamic commercial banks for the 2015-2020 period. The sample in this study was taken using the purposive sampling method with certain criteria. Based on the predetermined criteria, the sample used is 8 samples with a total of 48 data. The analytical method used is Descriptive Statistics, Classical Assumption Test, Multiple Linear Regression Analysis, Coefficient of Determination Test, and Hypothesis Testing using an analytical tool in the form of SPSS (Statistics Product and Service Solutions). The results of this study indicate that: mudharabah financing has a positive effect on banking performance, musyarakah financing has a negative effect on banking performance, murabahah financing has a negative effect on banking performance, ijarah financing has a positive effect on banking performance.
\end{abstract}

Keywords: Mudharabah, Musyarakah, Murabahah, Ijarah, Financial Performance.

\section{PENDAHULUAN}

Berkembangnya perbankan di Indonesia didasari oleh kepercayaan masyarakat untuk menyimpan dana dan mendapatkan penyaluran dana melalui perbankan terutama perbankan syariah. Hal ini dikarenakan sebagian besar penduduk di Indonesia beragama islam, perbankan syariah berdasarkan prinsip syariah serta perbankan syariah memberikan produk jasa yang mempermudah masyarakat, pelaku usaha maupun perusahaan untuk bertransaksi sehingga bank syariah akan terus berkembang dan memiliki eksistensi dimata masyarakat.

Dengan berkembangnya perbankan syariah maka diperlukan untuk menilai baik atau buruknya kondisi suatu perbankan yang salah satu dilihat dari Kinerja Perbankan. Kinerja perbankan merupakan pencapaian yang dilakukan oleh perbankan pada periode tertentu yang menggambarkan tingkat kesehatan suatu perbankan. Kinerja Perbankan diukur dengan menggunakan Capital Adequancy Ratio (CAR). CAR merupakan rasio kecukupan modal yang digunakan untuk mengukur kinerja suatu perbankan dalam menanggung risiko atas asset produktif dengan modalnya sendiri. Semakin tinggi nilai CAR maka semakin baik kinerja perbankan dalam menanggung risiko atas asset produktifnya dengan modalnya sendiri. Sebaliknya, semakin rendah nilai CAR maka semakin rendah pula kinerja perbankan dalam dalam menanggung risiko atas asset produktifnya dengan modalnya sendiri.

Berikut merupakan grafik Kinerja Perbankan yang diukur menggunakan Capital Adequancy Ratio (CAR) pada bank umum syariah periode 2015-2020: 


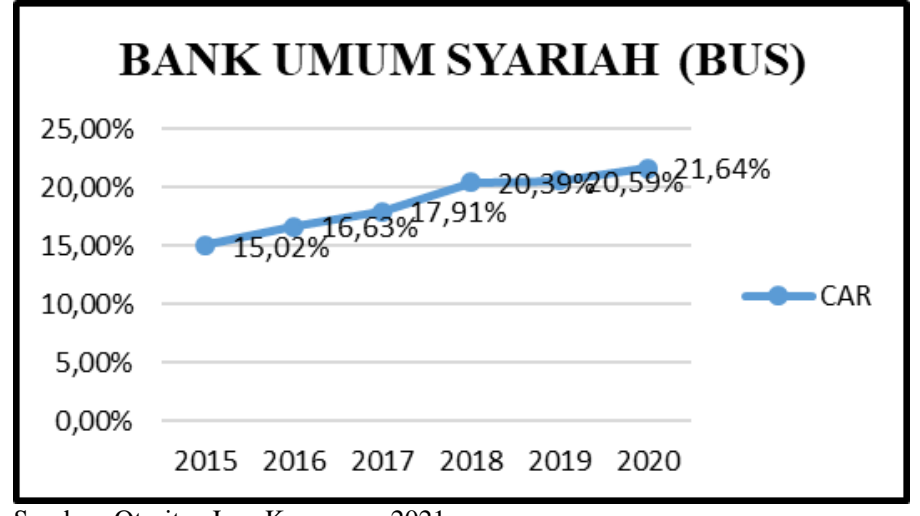

Sumber: Otoritas Jasa Keuangan, 2021

Berdasarkan grafik diatas dapat diketahui bahwa nilai CAR yang dimiliki bank umum syariah mengalami peningkatan. Peningkatan tersebut disebabkan oleh meningkatnya modal yang dimiliki oleh bank umum syariah.

Berikut merupakan Kinerja Perbankan yang di ukur dengan menggunakan CAR pada beberapa bank umum syariah periode 2015-2020:

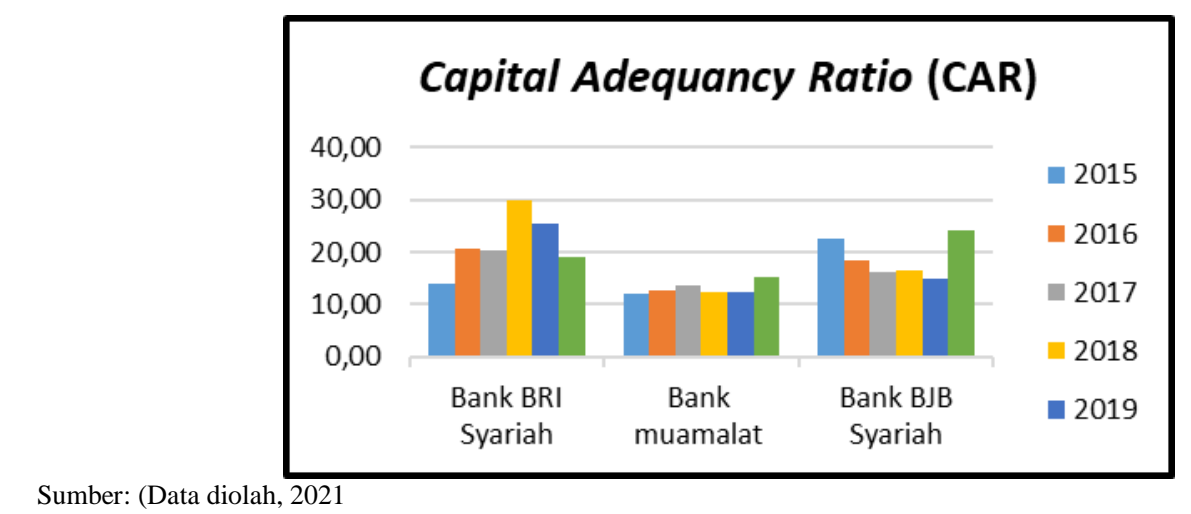

Berdasarkan gambar di atas dapat diketahui bahwa nilai CAR yang dimiliki oleh masingmasing bank mengalami fluktuasi. Fluktuasi tersebut disebabkan oleh modal dan ATMR yang dimiliki oleh masing-masing bank berbeda sehingga rasio kecukupan modal (CAR) juga mengalami perbedaan.

Dalam penggunaan asset keuangannya, Bank Umum Syariah memberikan produk penyaluran dana dalam bentuk pembiayaan. Pembiayaan yang digunakan dalam penelitian ini yaitu pembiayaan mudharabah, musyarakah, murabahah, dan ijarah.

Penelitian ini dilakukan pada Bank Umum Syariah karena berdasarkan statistika perbankan syariah bank umum syariah memiliki jaringan kantor terbanyak sehingga dapat dikatakan mampu untuk mewakili perbankan syariah serta Bank Umum Syariah merupakan bank Syariah yang menyediakan jasa pembayaran dalam kegiatannya. Dalam memberikan jasanya, Bank Umum Syariah juga dapat mempermudah masyarakat dalam menyimpan dana ataupun mendapatkan pendanaan dengan produk-produk jasa bank umum syariah. Dengan begitu bank umum syariah dapat menarik daya minat investor atau nasabah untuk melakukan transaksi di bank umum syariah sehingga seharusnya bank umum syariah memiliki prospek yang baik untuk kedepannya.

\section{Tinjauan Teoritis}

\section{LITERATUR REVIEW}

\section{Kinerja Keuangan}

Menurut Sutrisno, (2012:53) menyatakan bahwa "kinerja keuangan merupakan pencapaian dalam kurun waktu tertentu yang menggambarkan tingkat kesehatan perusahaan”. 
Bagi perbankan, penting untuk mengukur kinerja keuangan agar dapat memahami pencapaian manajemen dalam mengelola sumber daya. Adapun kinerja keuangan pada bank umum syariah diukur dengan menggunakan Capital Adequancy Ratio (CAR). Capital Adequancy Ratio (CAR) menggambarkan kemampuan perbankan dalam menanggung risiko atas asset produktifnya dengan menggunakan modalnya sendiri. Semakin tinggi nilai CAR maka akan semakin baik pula kemampuan perbankan dalam menanggung risiko atas asset produktifnya dengan menggunakan modalnya sendiri. Nilai CAR ditentukan oleh tinggi rendahnya suatu modal dan ATMR yang dimiliki. Semakin tinggi modal maka akan semakin baik pula kemampuan perbankan dalam menanggung resiko atas asset produktifnya sehingga nilai CAR akan meningkat. Sebaliknya, semakin rendah modal maka akan semakin rendah pula kemampuan perbankan dalam menanggung resiko atas asset produktifnya sehingga nilai CAR menurun.

\section{Pembiayaan}

Berdasarkan Undang-Undang No.21 tahun 2008 (pasal 1 angka 25) menyebutkan bahwa, pembiayaan adalah penyediaan dana atau tagihan yang berupa transaksi bagi hasil dalam bentuk mudharabah dan musyarakah, transaksi sewa-menyewa dalam bentuk ijarah muttahiya bittamlik, transaksi jual beli dalam bentuk piutang murabahah, salam dan istishna, transaksi pinjammeminjam dalam bentuk piutang qardh, dan transaksi sewa-menyewa jasa dalam bentuk ijarah untuk transaksi multijasa.

\section{Pembiayaan Mudharabah}

Menurut PSAK 105 menyatakan bahwa, Mudharabah adalah akad kerjasama usaha antara dua pihak dimana pihak pertama (Pemilik dana/ Shahibul Maal) menyediakan seluruh dana, sedangkan pihak kedua (pengelola modal/ mudharib) bertindak selaku pengelola, dan keuntungan dibagi sesuai kesepakatan sedangkan kerugian finansial hanya ditanggung oleh pemilik dana. Apabila kerugian terjadi karena kelalaian atau kesengajaan dari pihak pengelola maka pihak pengelola harus menanggung kerugian tersebut. Jadi Pembiayaan Mudharabah adalah akad pembiayaan yang dilakukan oleh pemilik modal dan pengelola modal dimana modal tersebut diperoleh dari pemilik modal dengan ketentuan keuntungan akan dibagikan sesuai nisbah keuntungan yang telah disepakati. Apabila terjadi kerugian usaha maka sepenuhnya akan ditanggung oleh pemilik modal, tetapi apabila kerugian tersebut terjadi karena kelalaian pihak pengelola maka pengelola modal harus menanggung kerugian tersebut.

Dalam transaksi mudharabah harus berdasarkan kepercayaan. Kepercayaan disini bermaksud pemilik modal harus percaya kepada pengelola modal. Karena dalam mudharabah pemilik dana tidak terlibat dalam mengelola usaha. Pemilik dana hanya diperkenankan untuk memantau dan memberikan saran kepada pengelola dana terkait usaha atau kegiatan tersebut (Nurhayati dan Wasilah, 2019).

\section{Pembiayaan Musyarakah}

Sedangkan menurut PSAK 106 mendefinisikan bahwa, musyarakah merupakan akad kerjasama antara dua orang atau lebih untuk suatu usaha tertentu, dimana masing-masing pihak memberikan kontribusi dana dengan ketentuan bahwa keuntungan dibagi berdasarkan kesepakatan sedangkan kerugian berdasarkan porsi kontribusi dana. Jadi pembiayaan musyarakah adalah akad pembiayaan yang dilakukan oleh dua orang atau lebih untuk menjalakan suatu usaha dimana modal tersebut diperoleh melalui kontribusi dana dari masing-masing pihak dengan ketentuan keuntungan akan dibagikan sesuai dengan nisbah keuntungan yang telah disepakati. Apabila terjadi kerugian maka masing-masing pihak wajib menanggung kerugian tersebut sebesar kontribusi dana.

Dalam musyarakah, para mitra harus bersama-sama berkontribusi baik dalam modal ataupun kerjasama dalam mengelola usaha tersebut. Kontribusi modal yang disalurkan oleh setiap mitra digunakan untuk membiayai usaha tersebut sedangkan kontribusi kerjasama antar para mitra berguna untuk mengelola usaha tersebut. Dengan bergabungnya lebih dari 2 orang mitra 
diharapkan akan lebih baik pengelolaan usahanya dikarenakan bertambahnya wawasan, keahlian yang berbeda-beda, pengendalian yang lebih memadai, serta relasi bisnis yang bertambah banyak (Nurhayati dan Wasilah, 2019).

\section{Pembiayaan Murabahah}

Menurut PSAK 102 mendefinisikan bahwa, Murabahah adalah akad jual beli barang dengan harga jual sebesar biaya perolehan ditambah keuntungan dan penjual harus mengungkapkan biaya perolehan barang tersebut kepada pembeli..Hal yang membedakan antara jual beli biasa dengan jual beli dengan akad murabahah yaitu pada jual beli dengan akad murabahah penjual memberitahu kepada pembeli mengenai harga pokok barang tersebut ditambah dengan keuntungan yang diinginkan. Penjual dan pembeli dapat melakukan tawar-menawar atas besaran margin keuntungan sehingga akhirnya disepakati oleh kedua belah pihak.

Penjualan dapat dilakukan secara tunai atau kredit (pembayaran tangguh). Penjual dapat meminta uang muka kepada pembeli sebagai bukti keseriusan ingin membeli barang tersebut. Barang yang sah untuk diperjualbelikan yaitu barang yang telah menjadi hak milik penjual. Uang muka akan menjadi bagian pelunasan piutang murabahah jika akad murabahah disepakati. Namun apabila penjual telah membeli barang dan pembeli membatalkannya maka uang muka tersebut dapat dijadikan sebagai penutup kerugian akibat pembatalan pesanan tersebut. Apabila jumlah uang muka lebih kecil dibandingkan jumlah kerugian yang ditanggung maka penjual dapat meminta kekurangannya kepada pembeli. Sebaliknya, apabila uang mukanya lebih besar daripada kerugian tersebut maka pembeli berhak untuk mendapatkan kembali sebagian uangnya.

Dalam akad penjualan kredit, apabila pembeli dapat melunasi hutangnya lebih cepat maka penjual dapat memberikan potongan namun potongan tersebut tidak diperkenankan untuk disepakati pada saat berlangsungnya akad. Dan Apabila pembeli tidak dapat melunasi hutangnya sesuai dengan waktu yang telah ditetapkan, maka penjual tidak diperbolehkan untuk mengenakan denda atas keterlambatan pembayaran yang dilakukan oleh pembeli. Namun penjual dapat mengenakan denda kepada pembeli apabila pembeli tidak dapat melunasi hutangnya karena kelalaian yang diperbuatnya. Diberlakukannya denda bertujuan untuk memberikan sanksi atau hukuman bagi orang yang lalai agar lebih disiplin menjalankan kewajibannya dalam membayar hutang. Apabila pelunasan piutang tertunda karena pembeli mengalami kesulitan keuangan maka penjual hendaknya memberikan keringanan. Keringanan dapat berupa menghapus sisa tagihan, membantu menjual objek murabahah kepada pihak lain atau melakukan rekonstruksi piutang.

\section{Pembiayaan Ijarah}

Menurut Nurhayati dan Wasilah (2019: 135) mendefinisikan bahwa, Ijarah adalah akad pemindahan hak guna atas suatu barang atau jasa pada waktu tertentu dengan pembayaran upah sewa (ujrah). Dalam akad ijarah, pemberi sewa wajib untuk menyediakan asset yang dapat digunakan atau diambil manfaatnya. Apabila terjadi kerusakan yang mengakibatkan penurunan nilai manfaat dari asset yang disewakan serta bukan disebabkan oleh penyewa, maka pemberi sewa berkewajiban menanggung biaya pemeliharaan atas asset tersebut atau dapat mengganti dengan asset sejenis yang lainnya. Namun, apabila kerusakan tersebut disebabkan oleh kelalaian penyewa maka penyewa berkewajiban menanggung kerugian tersebut.

Dalam akad ijarah, pembayaran sewa dapat dibayar dimuka, ditangguhkan, ataupun diangsur sesuai dengan kesepakatan antara pemberi sewa dan penyewa. Apabila pembayaran dilakukan dimuka dan penyewa membatalkan akad tersebut, maka uang muka tersebut menjadi hak pemberi sewa. Apabila pembayaran ditangguhkan dan terjadi penundaan pembayaran akibat kelalaian penyewa maka dapat dikenakan denda dan akan digunakan sebagai dana kebajikan.

\section{Hipotesis}




\section{Pengaruh Pembiayaan Mudharabah Terhadap Kinerja Keuangan}

Pembiayaan Mudharabah adalah akad pembiayaan yang dilakukan oleh pemilik modal (bank) dan pengelola modal (nasabah) guna menjalankan suatu usaha yang mana modal tersebut diberikan oleh bank secara menyeluruh kepada pengelola modal (Ismail, 2016). Semakin tinggi tingkat pembiayaan mudharabah maka semakin tinggi pula laba yang dihasilkan sehingga berdampak pada semakin tingginya kontribusi laba dalam meningkatkan modal. Dengan semakin tingginya modal yang dimiliki oleh bank umum syariah maka akan semakin baik pula kemampuan perbankan dalam menanggung resiko atas asset produktifnya sehingga berdampak pada meningkatnya kinerja perbankan yang diukur dengan CAR.

Hal ini sejalan dengan hasil penelitian yang dilakukan oleh Fatimah dan Nana, 2021; Akhyar dan Ridwan, 2020; Marlizar dan Chandra, 2019 yang menyatakan bahwa Pembiayaan Mudharabah berpengaruh positif terhadap kinerja keuangan. Berdasarkan uraian tersebut, maka hipotesis yang dapat dirumuskan adalah sebagai berikut:

\section{$H_{1}$ : Pembiayaan mudharabah berpengaruh positif terhadap kinerja keuangan.}

\section{Pengaruh Pembiayaan Musyarakah Terhadap Kinerja Keuangan}

Pembiayaan Musyarakah adalah akad pembiayaan yang dilakukan oleh beberapa orang untuk membentuk suatu usaha yang mana modal tersebut didapat dari kontribusi kedua belah pihak (Ismail, 2016). Semakin tinggi tingkat pembiayaan musyarakah maka semakin tinggi pula laba yang dihasilkan sehingga berdampak pada semakin tingginya kontribusi laba dalam meningkatkan modal. Dengan semakin tingginya modal yang dimiliki oleh bank umum syariah maka akan semakin baik pula kemampuan perbankan dalam menanggung resiko atas asset produktifnya sehingga berdampak pada meningkatnya kinerja perbankan yang diukur dengan CAR.

Hal ini sejalan dengan hasil penelitian yang dilakukan oleh Hartati dkk, 2021; Akhyar dan Ridwan, 2020; Nurfajri dan Toni, 2019 yang menyatakan bahwa Pembiayaan Musyarakah berpengaruh positif terhadap kinerja keuangan. Berdasarkan uraian tersebut, maka hipotesis yang dapat dirumuskan adalah sebagai berikut:

\section{$\mathrm{H}_{2}$ : Pembiayaan Musyarakah berpengaruh positif terhadap Kinerja Keuangan.}

\section{Pengaruh Pembiayaan Murabahah Terhadap Kinerja Keuangan}

Murabahah adalah akad jual beli dimana penjual/bank dapat memberitahu mengenai harga perolehan dari asset tersebut serta dapat memberitahu mengenai keuntungan yang diinginkan kepada pembeli (Nurhayati dan Wasilah,2019). Semakin tinggi tingkat pembiayaan murabahah maka semakin tinggi pula laba yang dihasilkan sehingga berdampak pada semakin tingginya kontribusi laba dalam meningkatkan modal. Dengan semakin tingginya modal yang dimiliki oleh bank umum syariah maka akan semakin baik pula kemampuan perbankan dalam menanggung resiko atas asset produktifnya sehingga berdampak pada meningkatnya kinerja perbankan yang diukur dengan CAR.

Hal ini sejalan dengan hasil penelitian yang dilakukan oleh Melita dan Wagio, 2020; Choiriyah dan Fitria, 2019; Marlizar dan Chandra, 2019 yang menyatakan bahwa Pembiayaan Murabahah berpengaruh positif terhadap kinerja keuangan. Berdasarkan uraian tersebut, maka hipotesis yang dapat dirumuskan adalah sebagai berikut

\section{$\mathrm{H}_{3}$ : Pembiayaan Murabahah berpengaruh positif terhadap kinerja keuangan.}

\section{Pengaruh Pembiayaan Ijarah Terhadap Kinerja Keuangan}

Ijarah merupakan akad sewa-menyewa yang digunakan untuk mengambil manfaat dari suatu asset atau jasa yang diberikan oleh pemberi sewa serta sebagai imbalannya maka pemberi sewa akan mendapatkan upah atas penyewaan asset atau jasa tersebut. Semakin tinggi tingkat pembiayaan ijarah maka semakin tinggi pula laba yang dihasilkan sehingga berdampak pada semakin tingginya kontribusi laba dalam meningkatkan modal. Dengan semakin tingginya modal 
yang dimiliki oleh bank umum syariah maka akan semakin baik pula kemampuan perbankan dalam menanggung resiko atas asset produktifnya sehingga berdampak pada meningkatnya kinerja perbankan yang diukur dengan CAR.

Hal ini sejalan dengan hasil penelitian yang dilakukan oleh Hartati dkk, 2021; Akhyar dan Ridwan, 2020; Marlizar dan Chandra, 2019 yang menyatakan bahwa Pembiayaan Ijarah berpengaruh positif terhadap kinerja keuangan. Berdasarkan uraian tersebut, maka hipotesis yang dapat dirumuskan adalah sebagai berikut

\section{$\mathrm{H}_{4}$ : Pembiayaan Ijarah berpengaruh positif terhadap kinerja keuangan.}

\section{Variabel dan Pengukuran}

\section{METODE}

\section{Kinerja Perbankan (Y)}

Kinerja keuangan diukur dengan Capital Adequancy Ratio (CAR) dengan membandingankan modal dengan ATMR. Berdasarkan Surat Edaran Otoritas Jasa Keuangan Nomor 14 /SEOJK.03/2017, dirumuskan sebagai berikut:

\section{Variabel Independen}

$$
\mathrm{CAR}=\frac{\text { Modal }}{\mathrm{ATMR}} \times 100 \%
$$

\section{Pembiayaan Mudharabah (X1)}

Pembiayaan mudharabah diukur dengan menggunakan logaritma natura dari jumlah pembiayaan mudharabah (Nurfajri dan Toni, 2019). Maka dapat dirumuskan sebagai berikut:

Pembiayaan Mudharabah $=\mathrm{Ln}$

(Jumlah Pembiayaan Mudharabah)

\section{Pembiayaan Musyarakah (X2)}

Pembiayaan Musyarakah di ukur melalui Logaritma natura jumlah pembiayaan musyarakah (Nurfajri dan Toni, 2019). Maka dapat dirumuskan sebagai berikut:

Pembiayaan Musyarakah = Ln

(Jumlah Pembiayaan Musyarakah)

\section{Pembiayaan Murabahah (X3)}

Pembiayaan Murabahah diukur dengan menggunakan Logaritma natura jumlah pembiayaan murabahah (Nurfajri dan Toni, 2019). Maka dapat dirumuskan sebagai berikut:

Pembiayaan Murabahah $=\mathrm{Ln}$

(Jumlah Pembiayaan Murabahah)

\section{Pembiayaan Ijarah (X4)}

Pembiayaan ijarah diukur dengan menggunakan Logaritma natura jumlah pembiayaan ijarah (Nurfajri dan Toni, 2019). Maka dapat dirumuskan sebagai berikut:

\section{Pembiayaan Ijarah $=$ Ln (Jumlah \\ Pembiayaan Ijarah)}

\section{Populasi, Sampel, dan Sampling}

Populasi dalam penelitian ini meliputi bank umum syariah periode 2015-2020. Sampel 
dalam penelitian ini diambil dengan menggunakan metode purposive sampling dengan kriteria tertentu. Berdasarkan kriteria yang telah ditetapkan maka sampel yang digunakan sejumlah 8 sampel dengan jumlah data sebanyak 48 .

Tabel 1. Kriteria Pengambilan Sampel

\begin{tabular}{|l|l|c|}
\hline No & \multicolumn{1}{|c|}{ Keterangan } & Jumlah \\
\hline 1 & $\begin{array}{l}\text { Bank Umum Syariah yang terdaftar pada Statistik } \\
\text { Perbankan Syariah Otoritas Jasa Keuangan dan } \\
\text { Bank Umum Syariah yang mempublikasi laporan } \\
\text { keuangan periode 2015-2020. }\end{array}$ & 14 \\
\hline 2 & $\begin{array}{l}\text { Bank Umum Syariah yang tidak memiliki } \\
\text { kelengkapan data penelitian. }\end{array}$ & $(6)$ \\
\hline \multicolumn{2}{|c|}{ Jumlah sampel perusahaan } & 8 \\
\hline Jumlah Data sampel & 48 \\
\hline
\end{tabular}

\section{Metode Analisis Data}

Untuk menganalisis hubungan antara variabel independen dan variabel dependen, Teknik yang digunakan untuk analisis data pada penelitian ini menggunakan analisis multivariate serta diolah dengan menggunakan program SPSS (Statistic Product \& Sevices Solution). Metode analisis data pada penelitian ini terdiri dari: Statistika Deskriptif, Uji Asumsi Klasik, Analisis Regresi Linier Berganda, Uji Koefisien Determinasi, dan Uji Hipotesis.

\section{Hasil Penelitian}

\section{HASIL}

Analisis regresi linier berganda bertujuan untuk mengetahui atau menguji pengaruh variabel independen terhadap variabel dependen (Sujarweni,2019). Hasil analisis regresi linier berganda dapat dilihat pada tabel dibawah ini:

Tabel 2.

Hasil Analisis Regresi Linier Berganda

\begin{tabular}{|c|c|c|c|c|c|c|c|c|c|c|}
\hline \multicolumn{11}{|c|}{ Coefficients $^{\mathrm{a}}$} \\
\hline \multirow[b]{2}{*}{ Model } & \multicolumn{2}{|c|}{$\begin{array}{l}\text { Unstandardized } \\
\text { Coefficients }\end{array}$} & \multirow{2}{*}{$\begin{array}{l}\text { Standardized } \\
\text { Coefficients } \\
\text { Beta }\end{array}$} & \multirow[b]{2}{*}{$\mathrm{T}$} & \multirow[b]{2}{*}{ Sig. } & \multicolumn{3}{|c|}{ Correlations } & \multicolumn{2}{|c|}{$\begin{array}{l}\text { Collinearity } \\
\text { Statistics }\end{array}$} \\
\hline & B & Std. Error & & & & $\begin{array}{l}\text { Zero- } \\
\text { order }\end{array}$ & Partial & Part & Tolerance & VIF \\
\hline \begin{tabular}{l|l}
1 & (Constant)
\end{tabular} & 76,355 & 21,321 & & 3,581 &, 001 & & & & & \\
\hline $\begin{array}{l}\text { Pembiayaan } \\
\text { Mudharabah }\end{array}$ & 3,291 & 1,095 & ,663 & 3,007 & ,004 &,- 133 & ,417 &, 327 & ,243 & 4,118 \\
\hline $\begin{array}{l}\text { Pembiayaan } \\
\text { Musyarakah }\end{array}$ &,- 234 & 1,299 &,- 037 &,- 180 & ,858 &,- 320 &,- 027 & - & ,284 & 3,519 \\
\hline $\begin{array}{l}\text { Pembiayaan } \\
\text { Murabahah }\end{array}$ & $-5,980$ & 1,391 & $-1,264$ & $-\overline{4}$ &, 000 &,- 374 &,- 548 & -4 & ,137 & 7,309 \\
\hline $\begin{array}{l}\text { Pembiayaan } \\
\text { Ijarah }\end{array}$ & 1,526 & ,367 & ,574 & 4,158 & ,000 &, 166 & ,536 & ,452 & ,620 & 1,613 \\
\hline
\end{tabular}

Berdasarkan tabel 2., maka diperoleh persamaan regresi sebagai berikut:

$$
Y=76,355+3,291 \cdot X 1-0,234 . X 2-5,980 . X 3+1,526 . X 4
$$

Dari persamaan tersebut dapat diambil kesimpulan bahwa: 
1. Konstanta sebesar 76,355 menyatakan bahwa jika ada pembiayaan mudharabah (X1), Pembiayaan Musyarakah (X2), Pembiayaan Murabahah (X3), dan Pembiayaan Ijarah (X4) konstan atau tidak ada atau 0, maka kinerja perbankan yang diukur dengan CAR akan mengalami peningkatan sebesar 76,355.

2. Koefisien regresi pembiayaan mudharabah sebesar 3,291 menyatakan bahwa setiap penambahan 1 point pembiayaan mudharabah (X1), maka akan meningkatkan kinerja perbankan yang diukur dengan CAR sebesar 3,291. Dengan anggapan bahwa pembiayaan musyarakah, pembiayaan murabahah dan pembiayaan ijarah bersifat tetap.

3. Koefisien regresi pembiayaan musyarakah sebesar -0,234 menyatakan bahwa setiap penambahan 1 point pembiayaan musyarakah (X2), maka akan menurunkan kinerja perbankan yang diukur dengan CAR sebesar 0,234. Dengan anggapan bahwa pembiayaan mudharabah, pembiayaan murabahah dan pembiayaan ijarah bersifat tetap.

4. Koefisien regresi pembiayaan murabahah sebesar -5,980 menyatakan bahwa setiap penambahan 1 point pembiayaan murabahah (X3), maka akan menurunkan kinerja perbankan yang diukur dengan CAR sebesar 5,980. Dengan anggapan bahwa pembiayaan mudharabah, pembiayaan musyarakah, dan pembiayaan ijarah bersifat tetap.

5. Koefisien regresi pembiayaan ijarah sebesar 1,526 menyatakan bahwa setiap penambahan 1point pembiayaan ijarah (X4), maka akan meningkatkan kinerja perbankan yang diukur dengan CAR sebesar 1,526. Dengan anggapan bahwa pembiayaan mudharabah, pembiayaan musyarakah, dan pembiayaan murabahah bersifat tetap.

\section{PEMBAHASAN}

\section{Pengaruh Pembiayaan Mudharabah terhadap Kinerja Keuangan}

Berdasarkan hasil uji hipotesis dengan menggunakan uji t maka dapat diketahui bahwa nilai t hitung sebesar 3,007 dan nilai sig. 0,004. Hal ini menyatakan bahwa, pembiayaan mudharabah berpengaruh positif dan signifikan terhadap kinerja perbankan. Kondisi tersebut menujukkan semakin tinggi tingkat pembiayaan mudharabah maka akan meningkatkan laba sehingga berdampak pada semakin besar kontribusi laba dalam meningkatkan modal. Dengan semakin meningkatnya modal, maka akan semakin baik pula kemampuan perbankan dalam menanggung resiko atas asset produktifnya sehinga kinerja perbankan yang diukur dengan menggunakan CAR juga meningkat.

\section{Pengaruh Pembiayaan Musyarakah terhadap Kinerja Perbankan (CAR)}

Berdasarkan hasil uji hipotesis dengan menggunakan uji t maka dapat diketahui bahwa nilai t hitung sebesar $-0,180$ dan nilai sig. 0,858. Hal ini menyatakan bahwa, pembiayaan musyarakah berpengaruh tidak signifikan terhadap kinerja perbankan, kondisi tersebut mengindikasikan pembiayaan musyarakah merupakan salah satu pembiayaan yang paling banyak disalurkan oleh bank umum syariah serta paling banyak di minati oleh nasabah atau masyarakat sehingga memicu timbulnya resiko atas pembiayaan bermasalah seperti kredit macet, kurang lancar atau diragukan. Hal tersebut yang menyebabkan laba yang diperoleh mengalami penurunan sehingga berdampak pada semakin rendah pula kontribusi laba dalam meningkatkan modal. Dengan semakin rendah modal, maka akan semakin rendah pula kemampuan perbankan dalam menanggung resiko atas asset produktifnya sehingga kinerja perbankan yang diukur dengan CAR mengalami penurunan.

\section{Pengaruh Pembiayaan Murabahah terhadap Kinerja Keuangan.}

Berdasarkan hasil uji hipotesis dengan menggunakan uji t maka dapat diketahui bahwa nilai t hitung sebesar $-4,298$ dan nilai sig. 0,000. Hal ini berarti semakin tinggi pembiayaan murabahah maka akan menurunkan kinerja perbankan, kondisi tesebut dikarenakan pembiayaan murabahah merupakan pembiayaan yang paling banyak disalurkan oleh bank umum syariah serta paling banyak di minati oleh nasabah atau masyarakat sehingga memicu timbulnya resiko atas pembiayaan bermasalah seperti kredit macet, kurang lancar atau diragukan. Hal tersebut yang 
menyebabkan laba yang diperoleh mengalami penurunan sehingga berdampak pada semakin rendah pula kontribusi laba dalam meningkatkan modal. Dengan semakin rendah modal, maka akan semakin rendah pula kemampuan perbankan dalam menanggung resiko atas asset produktifnya sehingga kinerja perbankan yang diukur dengan CAR mengalami penurunan.

\section{Pengaruh Pembiayaan Ijarah terhadap Kinerja Keuangan.}

Berdasarkan hasil uji hipotesis dengan menggunakan uji t maka dapat diketahui bahwa nilai t hitung sebesar 4,158 dan nilai sig. 0,000. Hal ini berarti pembiayaan ijarah berpengaruh positif dan signifikan terhadap kinerja keuangan. Hal ini berarti semakin tinggi pembiayaan ijarah maka akan meningkatkan laba sehingga berdampak pada semakin besar kontribusi laba dalam meningkatkan modal. Dengan semakin meningkatnya modal, maka akan semakin baik pula kemampuan perbankan dalam menanggung resiko atas asset produktifnya sehinga kinerja perbankan yang diukur dengan menggunakan CAR juga meningkat.

\section{KESIMPULAN}

Pembiayaan mudharabah berpengaruh positif dan signifikan terhadap kinerja keuangan. Kondisi tersebut menujukkan semakin tinggi tingkat pembiayaan mudharabah maka akan meningkatkan laba sehingga berdampak pada semakin besar kontribusi laba dalam meningkatkan modal. Pembiayaan musyarakah berpengaruh negatif dan tidak signifikan terhadap kinerja keuangan. mengindikasikan pembiayaan musyarakah merupakan salah satu pembiayaan yang paling banyak disalurkan oleh bank umum syariah serta paling banyak di minati oleh nasabah atau masyarakat sehingga memicu timbulnya resiko atas pembiayaan bermasalah seperti kredit macet, kurang lancar atau diragukan. Hal tersebut yang menyebabkan laba yang diperoleh mengalami penurunan sehingga berdampak pada semakin rendah pula kontribusi laba dalam meningkatkan modal. Pembiayaan murabahah berpengaruh negatif dan signifikan terhadap kinerja keuangan. dikarenakan pembiayaan murabahah merupakan pembiayaan yang paling banyak disalurkan oleh bank umum syariah serta paling banyak di minati oleh nasabah atau masyarakat sehingga memicu timbulnya resiko atas pembiayaan bermasalah seperti kredit macet, kurang lancar atau diragukan. Hal tersebut yang menyebabkan laba yang diperoleh mengalami penurunan sehingga berdampak pada semakin rendah pula kontribusi laba dalam meningkatkan modal. Pembiayaan ijarah berpengaruh positif dan signifikan terhadap kinerja keuangan. Hal ini berarti semakin tinggi pembiayaan ijarah maka akan meningkatkan laba sehingga berdampak pada semakin besar kontribusi laba dalam meningkatkan modal. Dengan semakin meningkatnya modal, maka akan semakin baik pula kemampuan perbankan dalam menanggung resiko atas asset produktifnya sehinga kinerja perbankan yang diukur dengan menggunakan CAR juga meningkat.

Al-Qur'an Surah At-Taubah ayat 105

\section{REFERENSI}

Ahmadi. Edy Anas. 2020. Analisa Kinerja Keuangan Koperasi Dengan Pendekatan Laporan Keuangan Pada Koperasi Budi Luhur Di Ngaglik. Jurnal Dimensi. Jilid 9. Terbitan 1. Halaman 135-162

Akhyar, M., \& Nurdin, R. (2017). Pengaruh Pembiayaan Mudharabah, Musyarakah, dan Ijarah Terhadap Profitabilitas Pada Bank BNI Syariah Indonesia Periode 2014-2017. Jurnal Ilmiah Mahasiswa Ekonomi Islam, 2(1), 46-63.

April, P., Akuntansi, J. R., Ryad, A. M., Yuliawati, Y., Akuntansi, P. S., \& Ekonomi, F. (2017). Pengaruh Dana Pihak Ketiga (Dpk), Capital Adequacy Ratio (Car), Non Performing Finance (Npf) Terhadap Pembiayaan. Jurnal Riset Akuntansi Dan Keuangan, 5(3), 1535-1540.

Brigham, Eugene F. dan Houston, Joel F. 2014. Dasar-dasar Manajemen Keuangan Terjemahan.

Edisi 11. Jakarta: Salemba Empat.

Choiriyah, S., \& Fitria, A. (2019). Pengaruh Pembiayaan Syariah, Non Performing Financing Dan Intellectual Capital Terhadap Kinerja Keuangan. Jurnal Ilmu Dan Riset Akuntansi, 8. 
Cicik Mutiah, Wahab, \& Nurudin. (2020). Pengaruh Pembiayaan Jual Beli, Bagi Hasil, dan Pembiayaan Bermasalah Terhadap Kinerja Keuangan. Jurnal Ilmu Perbankan Dan Keuangan Syariah, 2(2), 223-242.

Citarayani, I., Quintania, M., \& Handayani, D. P. (2021). Pengaruh Capital Adequacy Ratio (CAR), Return On Assets (ROA), dan Non Performing Financial (NPF) Terhadap Penyaluran Pembiayaan pada Bank Umum Syariah yang Terdaftar di Otoritas Jasa Keuangan (OJK) Periode Tahun 2012-2019. Akuisisi: Jurnal Akuntansi, 17(1), 64-81.

Fahmi, Irham.2018. Pengantar Manajemen Keuangan. Bandung: Alfabeta.

Fatimah, imeh siti, \& Diana, N. (2021). Pengaruh Pembiayaan Mudharabah, Musyarakah Dan Non

Performing Financing Terhadap Return On Asset Pada Bank Umum Syariah. Jurnal Akuntansi, 8, 62-75.

Fatwa Dewan Syari'ah Nasional No.08/DSNMUI/IV/2000 Tentang Pembiayaan Musyarakah.

Hartati, D. S., Dailibas, \& Mubarokah, I. (2017). Pengaruh Pembiayaan Mudharabah, Pembiayaan

Musyarakah Dan Sewa Ijarah Terhadap Profitabilitas. Jurnal Riset Keuangan Dan Akuntansi, 3(1), 235-240.

Hery. 2015. Analisis Laporan Keuangan. Edisi 1. Yogyakarta: Center For Academic Publishing Services.

IAI. 2007. PSAK No. 102 Pernyataan Standar Akuntansi Keuangan Akuntansi Murabahah. IAI. 2007. PSAK No. 105 Pernyataan Standar Akuntansi Keuangan Akuntansi Mudharabah. IAI. 2007. PSAK No. 106 Pernyataan Standar Akuntansi Keuangan Akuntansi Musyarakah. Ifham, Ahmad. 2015. Ini Lho Bank Syariah. Jakarta: PT Gramedia Pustaka.

Ismail. 2016. Perbankan Syariah. Jakarta: Prenada Media.

Jensen, M \& Meckling, W. (1976). "Theory of The Firm: Manajerial Behavior, Agency Cost and

Ownership Structure". Journal of Financial Economics Vol.3. pp.305-360.

Kasmir, S.E., M. M. (2015). Analisis Laporan Keuangan (Edisi 8). Rajawali Pers.

Marlizar, \& Satria, C. (2019). Analisis Pembiayaan Murabahah, Musyarakah Dan Ijarah Serta Pengaruhnya Terhadap Profitabilitas Pt. Bank Aceh Syariah Cabang Meulaboh. Jurnal Mudharabah, 2(1), 1-11.

Melita, D., \& Wagiyo. (2020). Pengaruh pembiayaan jual beli terhadap kinerja keuangan pada bank syariah mandiri periode 2015-2018. Jurnal Ilmu Ekonomi Manajemen, 11(01), 1-18.

Nizar, A. S., \& Anwar, M. K. (2015). Pengaruh Pembiayaan Jual Beli, Pembiayaan Bagi Hasil Dan Intellectual Capital Terhadap Kinerja Keuangan Bank Syariah. AKRUAL: Jurnal Akuntansi, 6(2), 130.

Nurfajri, F., \& Priyanto, T. (2019). Pengaruh Murabahah, Musyarakah, Mudharabah, dan Ijarah terhadap Profitabilitas Bank Umum Syariah di Indonesia. Jurnal Monex, 8(2)(1), 1-18.

Nurhayati, S., \& Wasilah. (2019). Akuntansi Syariah di Indonesia (G. S. P.G (ed.); Edisi 5). Salemba Empat.

Scott, W. R. (2000). Financial Accounting Theory. 2nd edition. Canada: Prentice Hall.

Sujarweni, V. W. (2019). Metode Penelitian Ekonomi Dan Bisnis. Pustaka baru press.

Surat Edaran Otoritas Jasa Keuangan Nomor 14/SEOJK.03/2017 tentang penilaian tingkat kesehatan bank umum.

Sutrisno. 2012. Manajemen Keuangan Teori, Konsep dan Aplikasi. Yogyakarta: Ekonisia.

Spence, Michael. 1973. Job Market Signaling. The Quarterly Journal of Economics, Vol. 87, No.

3. (Aug., 1973), pp. 355-374.

Undang-Undangan Republik Indonesia Nomor 21 Tahun 2008 Tentang Perbankan Syariah.

Prof H. Imam Ghozali, M.Com, Ph.D, C. (2018). Aplikakasi Analisis Multivariate Dengan Program Ibm Spss 25 (Edisi 9). Undip.

Wahyuni, M. (2016). Pengaruh Volume Pembiayaan Bagi Hasil dan Pembiayaan Murabahah terhadap Kinerja Keuangan Bank Umum Syariah dengan NPF sebagai Variabel Moderasi. Jurnal Ebbank, 7(1), 1-10.

www.ojk.go.id (diakses pada April sampai Agustus 2021) 
Yaya, R., Martawireja, A. E., \& Abdurahim, A. (2018). Akuntansi Perbankan Syariah (Rosidah (ed.); edisi 2). Salemba Empat.

Yunita, A., \& Fitri, M. (2020). Pengaruh Pembiayaan Musyarakah, Market Share Dan Modal Intelektual Terhadap Kinerja Keuangan Pada Bank Umum Syariah Di Indonesia. Jurnal Ilmiah Mahasiswa Ekonomi Akuntansi, 5(3), 344-361. 